Studia UBB \$Iigitalia, Volume 63 (LXIII) 2018, June, Issue 1, 7-29

Published Online: 2018-06-30

DOI:10.24193/subbdigitalia.2018.1.01

\title{
Between myth and stereotype: the method of studying the images of Russia in the visual media culture of Japan
}

\author{
Yashchenko Yulia V.*, Yashchenko Anatoly V., \\ Fadeeva Anastasia S. \\ Perm State University, \\ *yaschenko.jfenc@gmail.com
}

\begin{abstract}
The main sets of symbols of Russia in the visual media culture of Japan are formed in the $X X$ century. This period was saturated with military conflicts and under the conditions of a bipolar political system; reactionary images with noticeable militaristic influence were formed. This study was performed on the materials of visual media culture in Japan, sources such as anime and manga were studied, in which a high concentration of Russian images is observed. During the study of these sources, a complex of several hundred visual and verbal images of Russia was identified, which seems to be a unique phenomenon. Since such an interest in the country-opponent in foreign policy issues is nowhere else observed. The purpose of this study is to identify markers that denote the space of Russian images in individual visual sources and determine their place in the media culture as a whole. Accordingly, the main objective of the study became the development of methods based on approaches of Digital Humanities and Visual Studies. This study allows us to determine the most economically viable images of Russia in the Japanese media industry and makes it possible to use the results of the research in Russia's state image by stimulating Japan's visual media culture sector for representation the most auspicious images.
\end{abstract}

Keywords: visual studies; manga; intercultural communications; digital technologies 
The development of Russian-Japanese relations is an important direction in the political history of Russia. Domestic researchers pay considerable attention to the problems of political and economic contacts of these countries. The relationships between the countries developed in a complex political environment throughout the 20th century, which left an indelible imprint on the development of events at the present stage. Along with this, "gaps» are observed in historiography, especially in the field of studying the perceptions of the culture of the two countries (Yashchenko/ Ященко). Less attention is paid to the construction of the perception of the Russian state in Japan, the interpretation of its cultural landscape and the features of the formation of images of Russia in Japanese society (Ророva/ Попова). This study is devoted to the representation of Russia in the visual media culture of Japan. The study of the image of Russia is of interest because the Japanese media culture in a number of cases forms ideas about Russian reality in unique ways.

Media culture is a type of mass culture of the information society, which is a combination of information and communication tools, printed and screen cultures, material and intellectual values (Thomas).

Under the «image of Russia» should understand a set of symbols, images and stereotypes accumulated in the social and historical memory of Japanese society and reflecting ideas about the geographic features of Russia, the relationship between countries, cultural characteristics and the appearance of the «Russian human». The formation of an image is a constant process of accumulating information about an object and the subsequent construction of ideas about it (Nikolaeva/Николаева).

The folding of stereotypes and the rethinking of Russia's cultural images in Japan were influenced by diplomatic relations complicated by a number of military and political conflicts throughout the 20th century (Yashchenko/ Ященко). At the same time, the cultural and historical section of the end of the 20th - beginning of the 21st century - implies the presence in the content of the concept of "the image of Russia" epistemological installations of several eras that succeeded each other over several centuries of development of Russian-Japanese relations.

The military crisis of 1905 for many years complicated the political relations of countries, the Russian society for a long time experienced trauma after the shameful defeat for the big power. Revanchist sentiments in Russia, which took place in the second decade of the 20th century, Japan's aggressive policy in the Asian region adversely affected the political climate between countries. Despite a certain easing in the years of the First World War, it is impossible to give an unambiguous description of this stage, since for Japan during this period the priority direction was JapaneseAmerican relations. 
In the future, the crisis of relations occurs during the Second World War, which finally destroys the ties of Japan and Russia for more than fifteen years. Political tension was partially eliminated only in 1956 with the signing of the Soviet-Japanese intergovernmental Declaration, on the basis of which diplomatic contacts were restored. Despite the stabilization of political relations by the end of the 20th century, the outcome of the Second World War, which left a deep imprint on Japan's historical memory, conditioned the tense atmosphere of the development of Soviet-RussianJapanese relations in a broad sense (Kimura). The inhuman treatment of Japanese prisoners of war and the unresolved territorial issue also had a negative impact (Streltsov/ Стрельцов).

Of particular interest is the inconsistency and ambiguity of relations between Russia and Japa. To date, such an interest is fueled by the growing economic role of the Far Eastern region as a whole, as well as by the expansion of economic and cultural ties with Japan (Alepko/ Алепко). There is no doubt that the mutual relations strategies of these two countries are a unique phenomenon due to the absence of a peace treaty between them since the Second World War. In addition, we should not forget about the long-term territorial conflict with regard to the peninsula of Sakhalin and a number of coastal islands.

In the $X X$ century, the process of forming a political course in Russian-Japanese relations is continuing, but there is no clear prospect (Ророva/ Попова). Unambiguous in understanding the overcoming of differences is the need for dialogue with respect to the territorial problem, which today is one of the main stumbling blocks to concluding a peace treaty between countries (Visokov/ Высоков). This requires not only the transformation of the political course of countries, the strengthening of economic ties, but also the understanding of the mechanism of the influence of social attitudes and the political context on the formation and transformation of Russia's cultural stereotypes in Japanese society. In this connection, it seems necessary to conduct a detailed analysis of the Russian and Japanese relations in order to determine the key events that had a significant impact on the formation of ideas about Russia in the modern period in Japan.

Despite the keen interest in Russian-Japanese relations, the problems of intercultural communications and the origin of Russian images in Japanese society have been studied to a much lesser degree. In the Russian academic environment of orientalists, the topic of perception of Russian cultural images in Japanese society remains poorly researched. 
Probably, a small study of this problem area is due, first, to the complexity and ambiguity of Russian-Japanese relations, which requires a more detailed and indepth analysis of certain aspects of political and economic relations; Secondly, the fact that the topic is by definition a borderline, is at the junction of historical science, political science, cultural studies, and even sociology and psychology.

Features of the relationship between Japan and Russia in modern realities seems to be an urgent research issue. The problems of appearance and change of Russian images in the attitude of the Japanese are studied for a long time, attention is paid to the transformation of images, the formation of mutual stereotypes (Iguey/ Игуэ; Sidyakin/ Сидякин).

The products of the visual sector of Japanese media culture have recently become the subject of attention of scientists, manga and anime have become objects of cultural and social studies in the 2000s. In 2009, US scientists began to study the modern printed culture of Japan, however, not in the context of the problems of images, but in order to study the dynamics of the artistic style in comic images (Manovich).

This study is more focused on studying the content of Russian images, constructing intercultural communications between Russia and Japan, as well as analyzing Russian-Japanese political and economic relations, determining the degree of their influence on the appearance, transformation and interpretation of Russia's images. Of undoubted interest are the changes in political, economic and socio-spiritual aspects that are inextricably linked with the processes of transformation of Russian images. And thus, it fits into the mainstream of historical anthropology (Febvre/ Февр). One of the ideologists of historical anthropology, Peter Burke, writes that it is opposed to social history from the point of view of focusing not on quantitative data, but on qualitative data; on smaller groups of people, narrow problematic issues and sometimes focuses on cultural aspects. In his book «What is Cultural History?» P. Burke draws attention to the importance of the cultural aspect in the understanding of modern history and historical anthropology; he writes that the historical science in a broad sense stands on the way to the "cultural history of everything»: emotions, memory, gestures, humor, food and so on (Burke). In historical anthropology, the term «culture» has received a wide interpretation, implying under the cultural phenomenon any human activity: war, as a cultural phenomenon, historical memory, as a cultural phenomenon, etc. (Burke) This approach to the definition of the cultural field allows us to begin to study the narrower issues that are at the junction of several humanities. In addition, the anthropological approach in history draws attention to such aspects as perception, thinking and communication. P. Burke emphasizes that «perception has a history». And thus, it is historical science that should enter this field and, thanks to 
a retrospective view, give explanations for events that are taking place today or in the past, but which have an inseparable connection with the historical context. In addition, working with cultural phenomena allows history to develop, introducing into the scientific circulation sources of previously unused, but having a huge information potential. In this study, such a source is the objects of visual media culture in Japan, previously unused in such studies.

The theory of cultural research is based precisely on the search for a historical context and the interrelationships between cultural phenomena and historical events, between everyday life and the practices of mass culture (Barker). Images are constructed in the everyday field, taking into account the interests, needs, desires, values and of course the knowledge of ordinary people about the phenomenon or country (Berger). P. Berger and T. Luckman note that «the reality of everyday life» sometimes has a key influence on the perception of certain objects and events, since consciousness is intentional, then the focus on something (in this case on the images of Russia) presupposes the influence of external factors (Berger). In this way the same image can be interpreted by a specific individual in different ways in 1994 - during the period of aggravation of the situation on the Russian-Japanese borders, in 2005 diplomatic conflict on the background of the unresolved territorial issue and in 2010 the expansion of cultural communications and the increase in the number of economic contracts between Russia and Japan.

Based on the above, the research is based on the principles of an interdisciplinary approach, since in order to achieve the goal and objectives a symbiosis of historical science, cultural research and digital technologies is needed, which corresponds to the scientific paradigm of digital humanitaristics (Volodin/ Володин). The digital nature, heterogeneity and large volume of the research base (as will be discussed in more detail below) determined the relevance of the application of a number of methods of digital humanitaristics, as well as the use of appropriate software.

The hypothesis of the study is the assumption that the image of Russia in visual media is conditioned by the state of political relations between Japan and Russia that have a significant influence on the construction of perception of the «Russian» in the Japanese visual media culture and the significance of the historical context in the process of representation of the «Russian space».

The purpose of the study is to study the dynamics of the image of Russia in the visual media culture of Japan and the features of constructing its content, as well as to identify the relationship between image changes and the state of RussianJapanese relations. 
Among the main tasks of the project can be identified: the definition of the main historical and cultural images of Russia in Japan, the identification of their forms and types and economic opportunities of products of the Japanese visual media culture.

The chronological framework covers the period from 1993 to 2005. The choice of 1993 is due to Japan's recognition of Russia as the successor of the USSR (the Tokyo Declaration on Russian-Japanese Relations). The declaration confirmed the question put by Russia in 1991 about the decision of the position of the Kuril Islands (the political course of the Soviet Union did not allow the possibility of such a dialogue). In 2005, the thaw period ends, as relations between countries deteriorate sharply due to Japan's refusal to accept the terms of the 1956 Declaration, and the peace treaty was never concluded.

In the course of the study, images of Russia were studied on the materials of visual media culture of Japan, published in the period from 1993 to 2005. The media sphere of Japan actively uses various images of Russia in the process of content formation, inscribes the Slavic and Russian characters in the plot, demonstrates architectural and cultural objects. And despite the ambiguous state of affairs in foreign policy, interest in the Russian side is definitely growing in the period since the 1990s. Such a high concentration of Russia's images in the media culture really seems to be a unique phenomenon, since no country in the world represents such a broadly Russia in the entertainment industry (Yashchenko/ Ященко).

Media culture in Japan occupies a special place, it is widespread and is included in the everyday life of a significant proportion of the population. The product of the media culture is oriented to different age categories, which allows to cover sufficiently broad masses of the population in the analysis (the age graduation of the product covers the population of Japan from preschool to adulthood). A large proportion of the sources used in the study are targeted to an audience of 12 to 18 years and older, since comics and serials that show the most frequently images of Russia are addressed to the middle and older age groups. In addition, animated films are often included in the curriculum of Japanese secondary schools, an example is the animated picture dedicated to the events of the Second World War «Grave of the Fireflies»" 1.

As the main source of information for the study was chosen animation anime and traditional comics - manga (Manovich). It should be noted that the study does not aim to form an objective picture of the perception of Russia in society. On the contrary, the direct interest is precisely the set of images of Russia in the artistic

\footnotetext{
${ }^{1}$ Могила светлячков [Hotaru no haka] [Электронный ресурc] URL: https://goo.gl/9hvwrA (Accessed 16 June 2018).
} 
sphere, since such a representation of the country-rival in the animation and literary space is a unique phenomenon. And despite the fact that the media are excluded from sources, the concentration of Russian subjects remains quite high. This causes a special research interest, it is hardly possible to find even one more country with which there would be equally ambiguous relations, but at the same time a high interest in culture and historical events.

Traditional manga comics in Japan are valued not only as a literary work, but also as a visual art. There is a large number of printed products in the style of Japanese graphic novels, which are oriented specifically to the adult audience, often the stories are devoted to topical political issues.

The popularity of comic books also determined the pluralism of the subjects. The study used manga of the following genres:

1. Classical genres of Japanese literature: kodomo, syonen, shyojo, sainen, josei, dobutsu, jambar, jidai-geki, ken-geki, soshimin-geki;

2. Other genres of popular literature: cyberpunk, steampunk, fantasy, science fiction, space opera, apocalyptic, post-apocalyptic, romance, mysticism, comedy, drama, detective, psychological thriller, parapsychology, thriller, horrors, etc.

For the analysis of animated films and serials, the paintings were also selected for the above genres, in view of the fact that the anime is mainly drawn on the basis of manga, classical genres are also relevant to it.

The most popular genres are syonen and shoinze. Shounen is a genre targeted at a male audience aged 12 to 18 years, its share is about $34.8 \%$ of the total number of media culture products (Brenner). Shoandze, accordingly, is targeted at the female audience, the annual edition of the Shonji of twelve leading publishing houses of Japan (such as Ciao, Nakayoshi, Ribon, etc.) amounted to more than 3.5 million copies in $2004^{2}$. And most of the publications are weekly. If you look at general statistics on the main genres of the Japanese comic books, then in the year more than 23 million copies were released only in Japan in 2004-2006. The above statistics apply to comic books, but the animation series are similar, since a large proportion of anime is removed from the manga, but the series are shown on Japanese television, distributed on DVD-discs, their audience is much larger. So, if you look at the data of the Japanese Foreign Trade Organization (JETRO), submitted in 2004, the cost of the anime sector in the Japanese entertainment industry (that is, on the domestic market) was $\$ 24$ billion, and in the foreign market in 2005, the cost anime was 18

\footnotetext{
2 Manga Anthology Circulations 2004-2006. [Электронный ресурс] URL: http://www.comipress.com/article/2007/12/26/3040 (Accessed 17 June 2018).
} 
billion dollars ${ }^{3}$. For example, only in the United States in 2005 the sales of anime amounted to 5.2 billion dollars. For comparison, in aggregate for 2005, only the implementation of Japanese animation products in the domestic and foreign markets brings in at least $\$ 40$ billion, which is about 3.5-4\% of Japan's GDP ${ }^{4}$. Thus, the selected sources are interesting from the point of view of popularity, demand in Japanese society (см. Приложение 1).

The source of the research consists of a sample of Japan's visual media culture, which includes animated series and films (anime), as well as traditional comics (manga). In the course of the study, about 350 sources were analyzed and a sample of 130 sources was formed, in which images of Russia are presented. These sources were first introduced into scientific circulation, since they were not used before in Russia and abroad for historical or historical-cultural and political studies. The early analysis of the Japanese comic books was mainly conducted from the point of view of art and linguistic problems.

One of the difficulties in working with these types of sources is a large amount of information that can not be involved in the study. Series mainly consist of several seasons (from 2 to 4), each of which from 12 to 24 series lasting from 20 to 30 minutes. Often the image of Russia is represented only in some episodes of the season.

In the case of comics, the main problem is that they are published in black and white and it is impossible to single out, for example, the characteristics of the appearance of the Russian character. But comparative analysis of the manga with the animated product can help here, since the scenarios of most serials are based on comic books and thus partial verification of visual information in the same products of media culture is possible.

To organize the sources, a database was created, consisting of 14 tables; at the moment it contains over nine thousand records in total and about five thousand entries related to Japan's visual media culture. In the future, the database will be replenished.

The main tables of the database contain information about media culture objects, the maximum possible full characterization of the characters in the paintings in question (anthropometric data, a description of the nature, type of activity, key biographical events, etc.), historical and architectural objects and objects containing references to Russian culture.

\footnotetext{
${ }^{3}$ Scanning the Media.Japanese Anime - Within Sight of a 10 Trillion Yen Global Markets. [Электронный ресурс] URL:https://web.archive.org/web/20050310035337/www.jmrlsi.co.jp/english/inthemedia/ scan/2005/01.html (Accessed 17 June 2018).

${ }^{4}$ Japan GDP - Gross Domestic Product. [Электронный ресурс] URL: https://countryeconomy.com/gdp/japan?year=2005 (Accessed 16 June 2018).
} 
Russia's reception in the visual media culture of Japan (animated films, animated series and comics) is multifaceted, reflects the historical context of the development of Soviet-Japanese and Russian-Japanese relations, demonstrates ideas about the personality and appearance of a Russian. Studying this source, you can track what changes the ideas of Russia have undergone in time or in connection with various events, how various historical events were demonstrated and the most popular images were revealed.

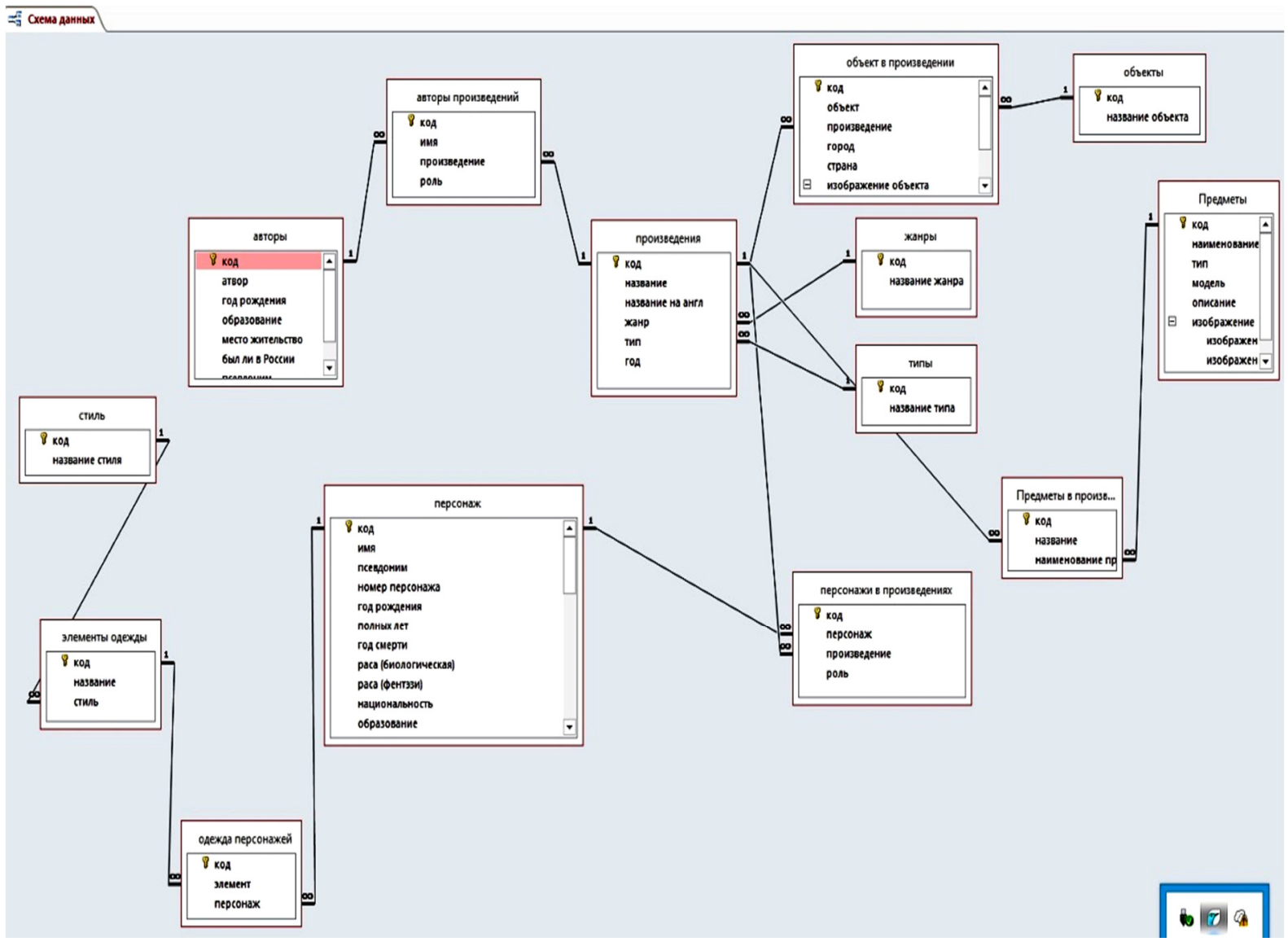

Fig. 1. Database schema «Images of Russia in the media culture of Japan»

In the course of the study, militaristic tendencies of the representation of Russia in the 1990s were revealed. With a deeper analysis of the sources, it was possible to establish that these or other images of war take their origins in the historical context of the development of Russian history and Soviet-Japanese relations.

In the light of the humanization of society, the change in the strategy of international relations, militarism acquires a more negative semantic coloring (Rusakova/ Русакова) and today such an image of the state can not be called 
neutral, since the saturation of the space of «Russianness» with weapons and military uniforms causes corresponding negative connotations not only in Japan but also beyond it, since this sector of media culture is very popular in the countries of Asia, Europe and Of America (Cooper-Chen).

For example, only North American countries accounted for more than 10 million manga readers at the beginning of the 2000s., not counting the audience of viewers of animated films and serials. No less popular products of Japan's visual media culture have become in Europe (Yomota/ Ёмота). Such popularity makes the chosen source more relevant, since the features of the representation of the image of Russia in the Japanese media culture are broadcast to many other countries and form the corresponding representations.

The analysis of the source base made it possible to reveal interest in Russia not only in the form of the representation of stereotyped images, such as the Moscow Kremlin, Basil's Cathedral of the Blessed One, but also the appeal to more complex images. The historical motives in a number of Japan's visual media culture facilities prompted the need to carefully study the historical context of Soviet-Russian-Japanese relations, since this would allow us to more deeply consider the origins of various representations of Russia and identify key historical events that left a notable mark on historical memory Japanese society, which is not even visible today.

Among such events, mention should be made of the Second World War, in particular the conclusion of a neutrality pact between the USSR and Japan in April 1941 (Rees). The document allowed Japan to strengthen its alliance with Germany (Rees). The document was ratified on April 25, 1941. According to the terms of the pact, it was concluded for five years and entered into force from the moment of ratification ${ }^{5}$. Thus, the treaty acted from April 25, 1941 to April 25, 1946, according to article 3 of the Neutrality Pact: «If none of the contracting parties denounce the pact a year before the expiration of the period, it will be automatically extended for the next five years».

It was the events of 1945 that marked the beginning of historical battles that broke out in the historiography of Japan and Russia in the post-war period and are still continuing today. The position of many Japanese politicians and scholars regarding the USSR's entry into the war with Japan is such that the Soviet Union is recognized as an aggressor who supported the idea of the allies only with the goal of territorial increments. It should be noted that the rhetoric from time to time is very sharp even in the academic environment, so you can encounter such formulations as «the

\footnotetext{
${ }^{5}$ Договор нейтралитета между Союзом Советских Социалистических Республик и Японией, от 13 апреля 1941 года. [Электронный ресурс]

URL: http://hrono.ru/dokum/194_dok/19410413jap.php (Accessed 7 May 2018).
} 
Russians treacherously violated the neutrality pact», the availability of this document allows Japan to put even modern Russia at a disadvantage and accordingly form a negative image of the Russian state in Japanese society (Vorobyeva/ Воробьева).

It is precisely the violation of the terms of the neutrality pact of 1941 that strengthens the corresponding view of the USSR, in cases where the rhetoric of Japanese scientists and diplomats remains consistent, the issue of the violation of the pact by the Soviet side. At the same time, by the 1990s, the mention of such facts does not sound in an accusatory tone, but is only given as collateral events. It is difficult to give an unambiguous assessment of such tendencies, but noting that Russian historiography looks at the problem of the violation of international agreements regarding Japan of this period (Slavinsky/ Славинский), it should be noted that on April 25, 1945 the Soviet Union, in the person of V.M. Molotov, at a meeting with Japanese Ambassador N. Sato, signed the denunciation of the neutrality pact of 1941. In fact, the pact was not annulled and formally retained its actions until April $1946 .{ }^{6}$

One of the popular justifications for violations of the USSR in article 3 of the neutrality pact of 1941 was, as dictated by the United States, the accusation of Japan atrocities in Pearl Harbor. As a consequence, the Tokyo Court of 1945 considered that the Japanese had to suffer the appropriate punishment. Thus, the outcome of the court session demonstrates a prejudiced decision of the «victors against the vanquished» (Slavinsky). The Soviet Union uses the argument that Japan, being an ally of Nazi Germany, which entered the war with the USSR, becomes an indirect participant in the war with Soviet Russia. However, the issue of political relations between the Soviet Union and Germany during the Second World War is clearly ignored, although those counterarguments that are addressed to Japan can be fully addressed to the USSR, since its plans did not originally include support for Western Europe.

The actions of the Soviet Union are subjected to Japanese criticism and for other reasons, for example, the Soviet leadership is accused of attacking the country that surrendered. For example, Chairman of the National Security Research Council Ichiro Suezugu notes that despite the signed surrender act of September 2, 1945, the imperial rescript to the Japanese Armed Forces was announced at noon on August 15, 1945, the troops retreated, but the Soviet army on East under the command of Commander-in-Chief A.M. Vasilevsky went on the offensive against the Northern Kurils. Thus, from the position of Japanese scientists and politicians of the USSR not only violated the terms of the neutrality pact of 1941, but also attacked the capitulating country.

\footnotetext{
${ }^{6}$ Soviet denunciation of pact with Japan (The Department of State Bulletin, Vol. XII, No. 305, April 29, 1945). [Электронный ресурc] URL: http://www.jewishvirtuallibrary.org/ussr-declaration-of-war-onjapan-august-1945 (Accessed 4 June 2018).
} 
The events of the Soviet invasion at the end of the Second World War largely predetermined the tendencies of the representation of Russia in Japanese society, which can be observed even in the 2000s. Rethinking Japan's role in Nazi aggression made it possible to criticize the actions of the USSR in 1945 and the territorial results of the conflict. The theme of the Second World War is widely represented in the visual media culture of Japan, in particular, the image of the USSR and the Soviet soldier. It is clearly impossible to assess the representation of the Soviet side in this context, it is not applicable to the gradation "positive» or «negative» each image represents a borderline phenomenon, where one can find echoes of both positive and negative meanings. As mentioned in the introduction, this study requires attention to the historical and cultural details of Japan, which correlates with the ideas of the New Cultural History (Darnton/ Дарнтон). Since it is impossible to look at such images from the standpoint of Russian reality, on the contrary, it is necessary to realize as precisely as possible the prerequisites for the appearance of a particular image and the conditions for its interpretation.

Taking into account the fact that in Japanese society the idea of the «historical fault of the USSR» regarding the above events is preserved, as described in his research by TA. Vorobyeva (Vorobyeva/ Воробьева), it becomes clear why the theme of the Second World War is popular even in modern media culture in Japan. For Japan, it became the same historical memory as it became for Germany and Russia (Assman/ Ассман).

Soviet historiography for a long time was built in accordance with the contextual framework of the political regime and did not recognize the violation of the conditions of the neutrality pact for the actions of the USSR, it would be more correct to say that this question was flexibly avoided. One of the first domestic researchers who violated the traditional interpretation of Japan's aggressive foreign policy was B. Slavinsky, who questioned in principle the ownership of the Southern Kuriles of Russia. However, he met with serious criticism in academic circles (Slavinsky).

In the media culture of Japan, reflections and little-known events were found. For example, the image of the Gulag was relevant for the visual media culture of Japan, and the prominence of this topic is connected with the massive release of memoirs of interned Japanese prisoners of war. Hence modern Japanese society knows about the Gulag system in the USSR, knows about the conditions in which their relatives and fellow citizens found themselves. Therefore, seemingly unobvious image has deep roots in the historical context of Japan. Such a discovery is very important, because it simultaneously demonstrates the importance of objects of visual media culture as a historical source for studying the features of representations and reflects the depth of the rethinking of historical events in Japanese popular culture. 


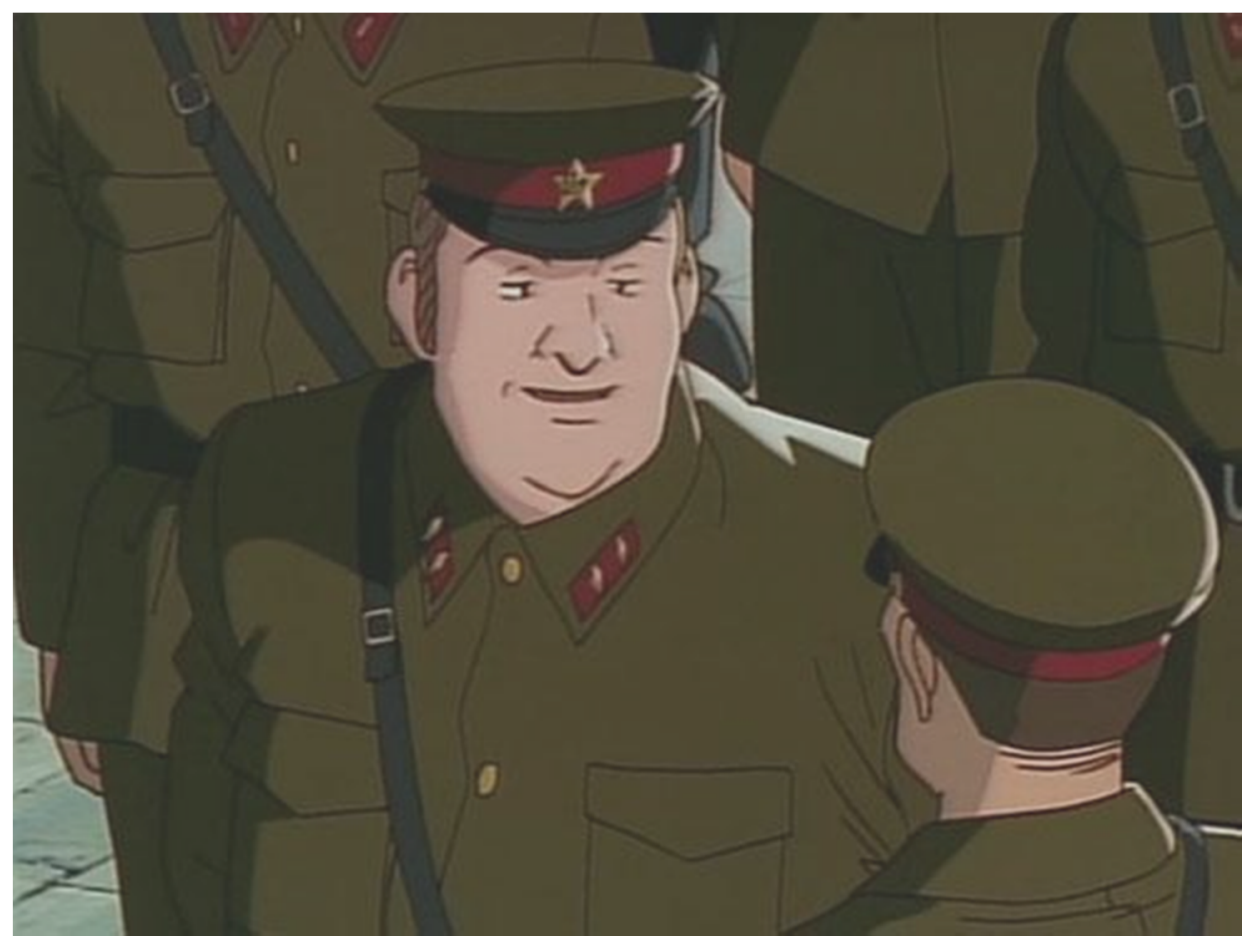

Fig. 2. The image of the Soviet military and Russia during the Second World War

In this regard, it is important to note that a significant share of the economy is built around the entertainment industry, which is due to the high popularity of this type of product. According to expert estimates, more than $95 \%$ of Japan's population read manga comics, the percentage ratio with anime differs slightly. Only in Japan, the circulation of popular youth magazines Shonen Jump and Shonen Magazine ranges from 1.5 to 3 million copies. These magazines are issued monthly and have foreign affiliates and Internet versions, so the relevance of this source in the context of the Japanese society does not cause doubts. In addition, directly manga is a major branch of Japanese book publishing and in 2009 the turnover was more than 420 billion yen. Thus, the process of demilitarization of the image, which began in the early $2000 \mathrm{~s}$, is really important because it constructs a more neutral view of Russia in the modern society of Japan and is conditioned, first of all, by the process of demilitarization of the image of Russia in Japanese society.

Turning to the analysis of images in the visual media culture, it should be noted that the fact that there is a large amount of snow in the location, presented in animated films and serials or comics, as a rule, already appeals to Russia and is used to mark the Russian space. But on the question of whether there can be snow only in the Russian way, there is a definite answer - no. Such an assumption would be erroneous, if only from the point of view of the uniqueness of these weather conditions, careful 
attention to detail in the frame is necessary in order to avoid working with «false images». Only a combination of these or other markers concludes that it is precisely the space of «Russianness» that is convincing.

For the analysis of images, descriptive statistics and content analysis methods were used. A three-dimensional description of visual and verbal images was developed for the study. Analysis of the visual component of the image, analysis of the semantic content of the image, analysis of the contextual information:

1. analysis of the visual component involves fixing the whole image presented in the objects of visual media culture;

2. content analysis provides for the identification of key words describing the image, as well as historical and cultural components of a particular unit of images;

3. analysis of contextual information implies the search and study of additional information about an image that is not part of a particular image.

This approach to the analysis of images is caused by interest in the history of Russia in animated products and comics, often it manifests itself in the use of architectural images.

Weather conditions are just one of a few examples, at this stage of the study, about 10 major groups of images were identified (for example, the group «nature» includes such images as snow, pine, birch, etc.). Thus, if you meet a snow-covered landscape and wooden structures in the animation (based on a selection of sources), this will often be correlated with Russian images. As a rule, they are accompanied by various markers, which reveal to the uninitiated this stereotype (posters, Cyrillic script, achievements of culture, etc.).

If a large proportion of images can be characterized as "frequency», then some are close to «unique» and seem most interesting. Among them is the image of the Gulag, demonstrated in several animated series. At the first acquaintance the question arises about the origin of the image, it would seem, with a high concentration of Russian weapons and architectural objectives, everything is more or less clear, but how to explain the appearance of the camp? The history of the origin of the image turned out to be deeper than one might have imagined before acquaintance with the historical events of the second half of the 20th century. In the aftermath of the Second World War in 1945, tens of thousands of Japanese prisoners of war were found on the territory of the Soviet Union, who were sent to Siberia camps for a long time. The conditions in which the prisoners were found did not differ from the standard conditions of the Gulag because they were sent to ordinary general areas where repressed Russians and criminals were held. 


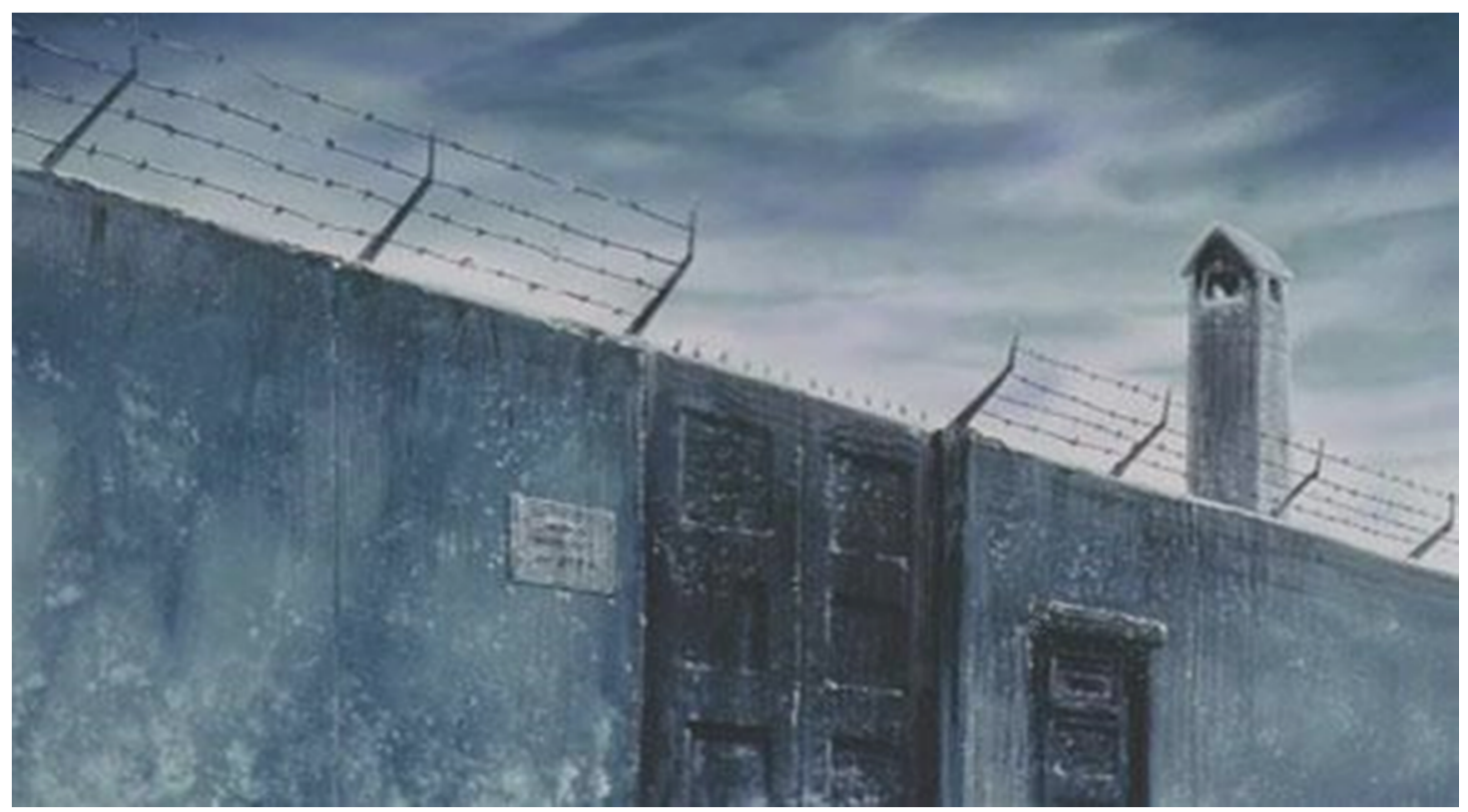

Fig. 3. Demonstration of the image of the Gulag in visual medicine of Japan

Not only the memoirs of the military returned to their homeland left such a deep trace in the historical memory of modern Japan, it is worth noting that in the second half of the 20th century, many Japanese citizens tried to come to the USSR to find family members or visit the graves of relatives, however, even after signing the Moscow Declaration of 1956, such actions were prohibited for the Japanese. Obviously, such measures were taken by the Soviet side with a view to concealing the scale of the deaths of prisoners of war and the problem of violation of their rights.

Within the framework of the study, images of Russian characters were also studied. For the analysis of Russian characters, a method was developed that was based on identifying key words describing character and behavioral standards of the character, external physiological characteristics on the basis of which the content analysis of text data and images was conducted. The relationship between external data, personality characteristics, sphere of activity and nationality of the character was established.

The screenshot shows the frequency of occurrence of certain characteristics of Russian characters. This way of visualization is intuitively understandable and allows you to get acquainted with the results of the analysis in a simple manner. If you pay attention to the thickness of the edges, then stand out such characteristics as «blond» and «blue». In the questionnaires of characters, the second characteristic was assigned to the color of the eyes and accordingly on this screenshot one can see the main trends in the image of the Russian character: a blond with blue eyes. 


\section{One-Саsе Модель}

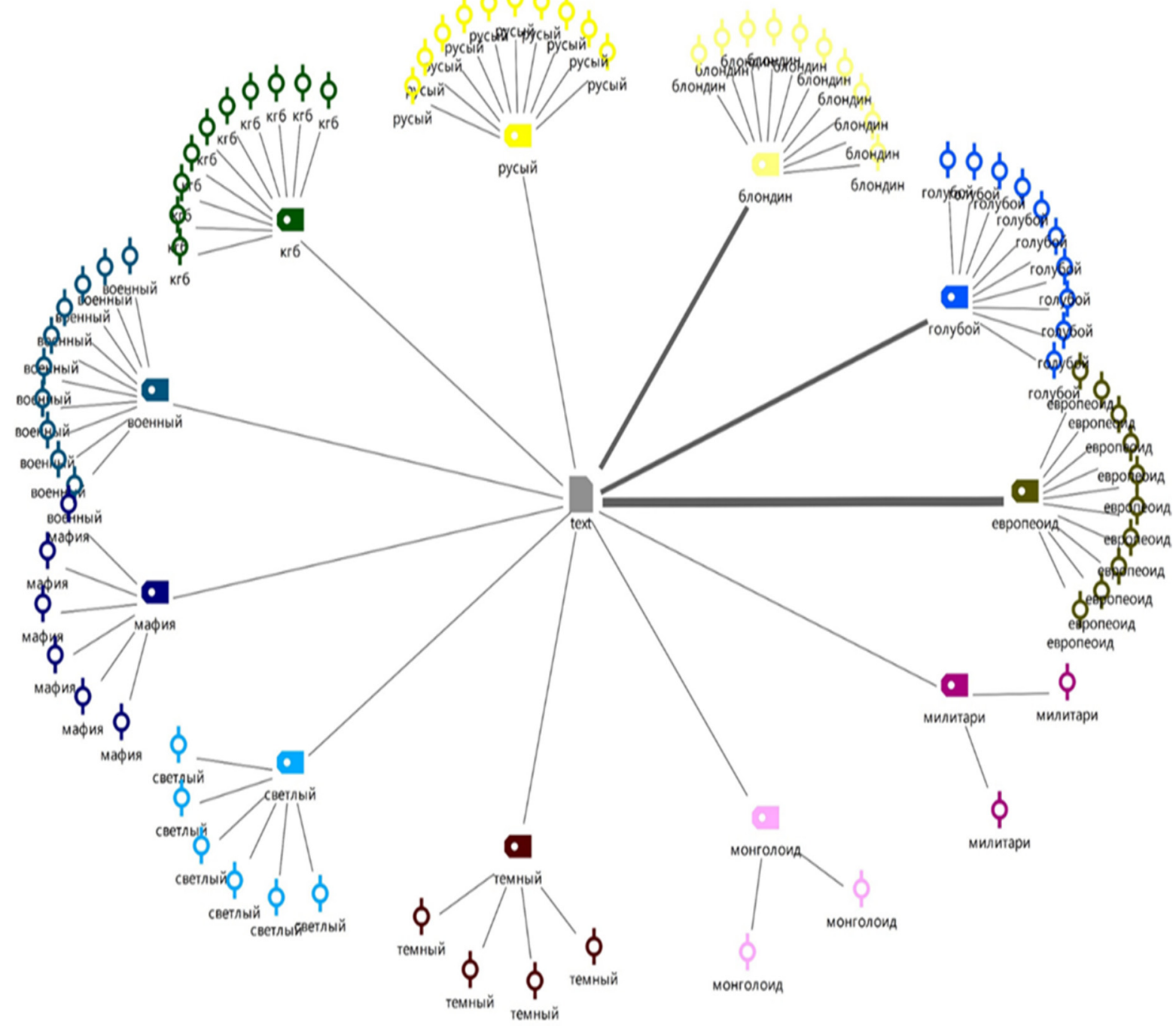

Fig. 4. Visualization of the results of content analysis of sources for the characteristics of Russian characters

The characteristics of the appearance and personal qualities of Russian characters, their activities, etc. were singled out, after which the sources were analyzed to identify the most common characteristics that are presented on the map. So, the color of the eyes prevails blue, the color of the hair is mostly blond and fair-haired.

The Russian character is endowed with a number of special traits of character and a fairly typed psycho-behavioral cliche, but in the guise there is always some militancy. It may not carry a threat to society, the character may not be military, but will have a certain character trait. For example, almost all characters have either a pronounced or 
mediocre expression of such quality as duty. In the interpretation of this characteristic it is worthwhile to go deeper into the traditional culture of Japan and turn to the development of Russian-Japanese relations. First, Japan was one of the militaristic countries for a long period, and secondly, it pursued a rather aggressive foreign policy aimed at creating the image of a strong state in the international political arena and, thirdly, speaking of Russian-Japanese relations, it is always about territorial conflict, complicated by a number of armed clashes on the border. These aspects make it possible to understand that Japanese traditions are close to state trends and military subjects, and the earlier history of the Japanese empire is permeated with the feats of samurai and internecine wars, at this level the concept of duty has been strengthened in a significant way in the soil of traditional culture and has acquired exceptionally positive characteristics, character with this quality, the completely explainable goal is pursued to betray, first, the ideal traits of a soldier from the point of view of the Japanese tradition, and, secondly, to emphasize feature of the nation. Mostly, the "sense of duty», of course, correlates with the military, however, this has to do with athletes, art people, scientists, doctors, etc.

Considering the personality characteristics, the most frequently mentioned characteristics were highlighted: a sense of duty, pride, stubbornness, and prudence. However, they do not have strong negative connotations. In principle, such evaluative judgments seem to be erroneous, since the adaptation of the characteristics from the point of view of the modern person from Russia will be unrepresentative with respect to reality, which the Japanese director models for the Japanese audience, first of all.

In the period from 1993 to 1995 , in the works the strongest militarization of the country is represented. In these years, Russian-Japanese relations are based on the principle of «tug-of-war», in the struggle for legitimizing rights to the Kuril Islands. Japan conducts a military and political provocation until 1994. In response, Russia withdraws troops to coastal areas. So, within the studied period, we observe the presence of contacts of Japanese society only with militarized Russia, which is reflected in the perception of the state as a whole. For this period, the largest ratio of military to civilian among the Russian characters. But in 1994 in Japan there is a strong earthquake, and Russia sends a humanitarian mission. Since 1994, the number of animated pictures has grown significantly and a new image is emerging - the image of a scientist, a doctor, more often turns to the idea of sacrifice, a duty. The growth of paintings in the period from 1995 to 2000 is associated with the expansion of «hot contacts» between states. 

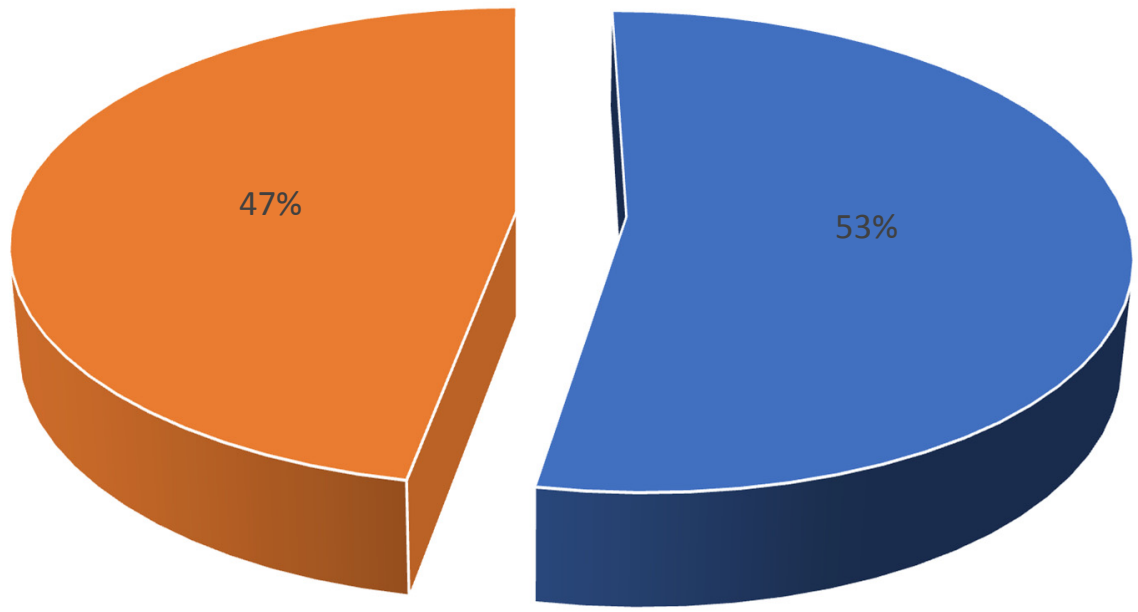

Fig.5. The ratio of military and civilian characters by the year 2000: $47 \%$ - ratio charters; $53 \%$ - military charters

The number of paintings with Russian characters is also growing, the peak is at the end of 2003 - the beginning of 2004 (about 50 works). And by 2005 it is again falling against the background of aggravated political disagreements.

Tendencies of militarization of the image of Russia, with further study of the chosen period, decreased significantly by 2005 . But the process of demilitarization does not occur due to the reduction of the representation of military characters or the reduction of the number of weapons, but thanks to the pluralism of civil images. The professional representation of Russian characters has expanded, statistics have shown that the number of military characters is declining after 2000. It can be assumed that for the Japanese of the generations of the Cold War, Russia is associated with the military sphere, but at the present stage the level of militarization is declining due to the expansion of intercultural communications and economic relations, significantly increased mobility of the population of countries. Throughout the period there has been a positive dynamic of the image of Russia, the number of military characters has decreased by an average of $30 \%$ (if in the 1990 s, about $50 \%$ of all military characters, then by 2005 less than $20 \%$ ). 


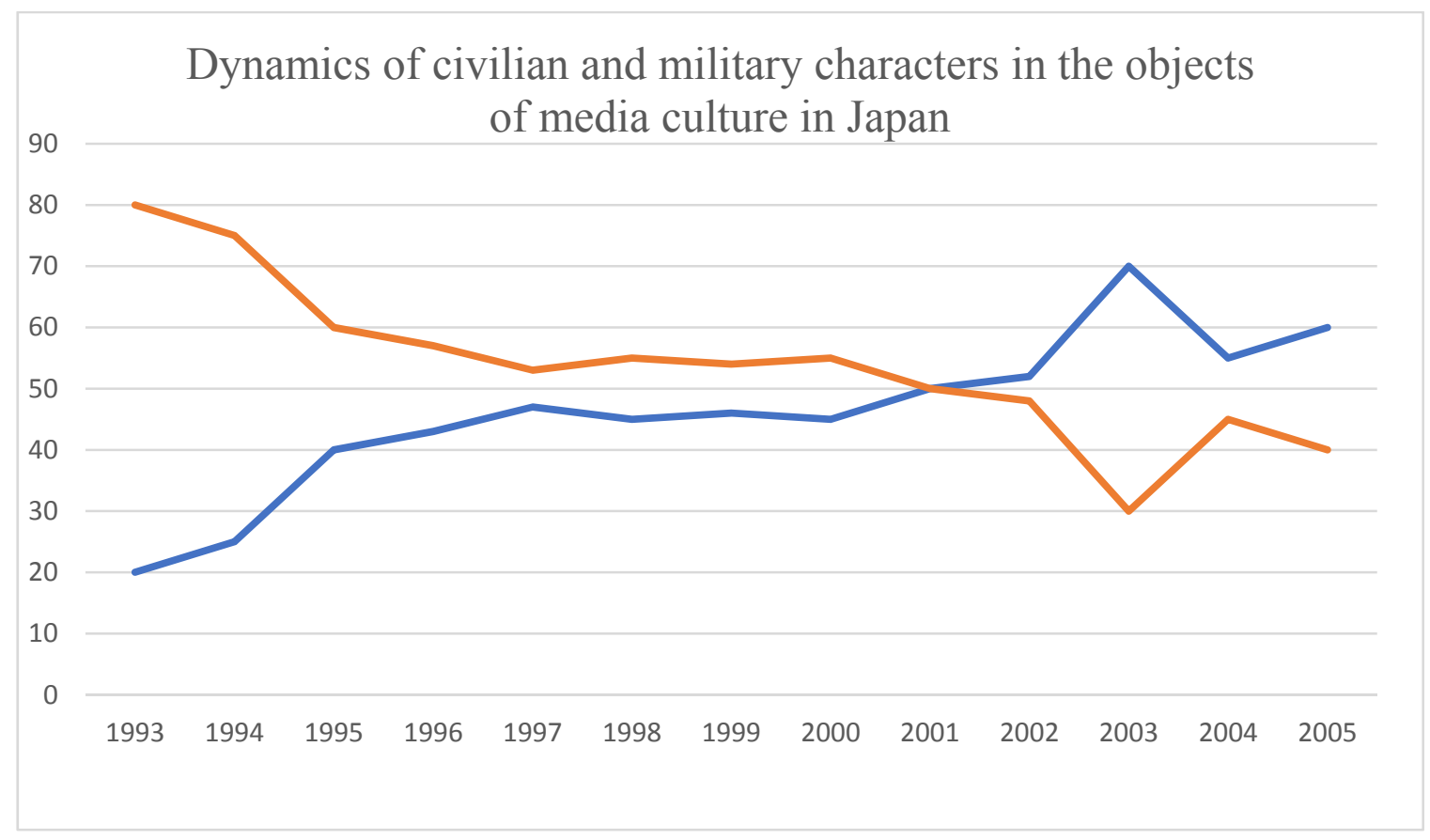

Fig. 6. Dynamics of civilian and military characters in the objects of media culture in Japan. The blue graph reflects the dynamics of civilian characters, yellow, respectively, military characters

Quite often the plots of Japan's media culture products appeal to historical events and personalities of Russia. Particularly often refer to the events of the 1917 revolution and to historical personalities who manifested themselves in that period. Most often there are references to the house of the Romanovs, there is a great interest and even sympathy for the personality of Nicholas II.

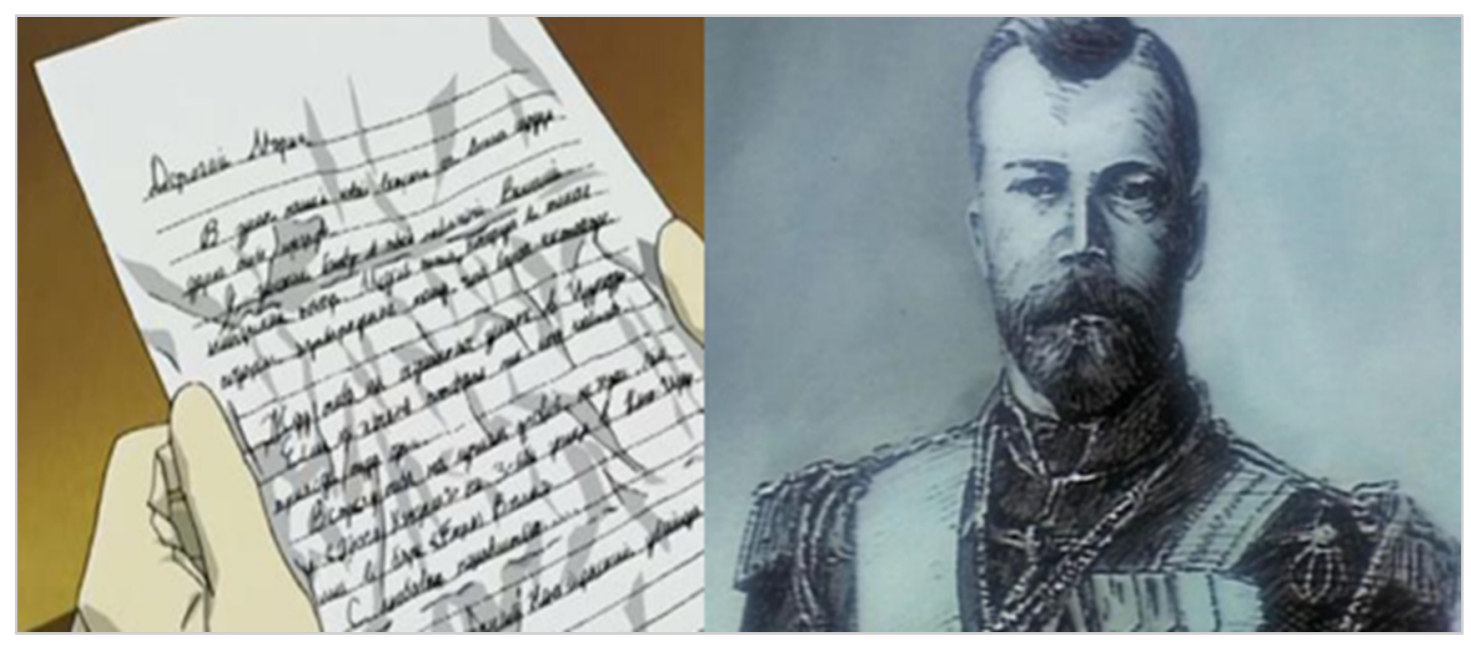

Fig. 7. Demonstration of images of Russia in the media culture of Japan 
In this connection, it is usual to recall GE. Rasputin, which can be associated with rooted mysticism in the traditional culture of Japan. It seems that this is due, above all, to the Japanese experience of the trauma of Russian society associated with the murder of the imperial family in 1918, which did not happen in Japan. This assumption seems less convincing than, for example, the explanation that the popularity of Nicholas II is due to his personal tragic fate and visits to the Japanese empire. Such interest in the Romanovs' house explains the frequency of occurrence of architectural objects in Yekaterinburg and, in principle, the popularity of the Urals region, since it is directly related to the history of the last Romanovs.

In addition to political figures or mystical figures entangled in legends, the creators of the work appeal to scientists and famous people of Russia throughout its existence. Among such people can be called the Queen and Gagarin, in general the topic of space conquest is very popular in Japan's visual media culture.

By the early 2000's. interest in the civil spheres of Russia demonstrates an increase in the number of images related to Russian culture and sport. So, if you pay attention to the literature presented in the animated pictures, you can see that these are mainly Dostoevsky's books, especially the «Brothers Karamazov» and "Crime and Punishment» are popular. This also has a real explanation, not the fiction of filmmakers and screenwriters, but quite a response to the consumer's request.

The results of the research demonstrated the presence of stable images of the Russian person, images that mark the Russian space and abstract appeals to climatic features and the natural landscape of Russia. As a rule, this is accompanied by other images that reveal to the uninitiated this stereotype (posters, Cyrillic script (inscriptions do not always represent words, sometimes they are only meaningless sets of letters), achievements of culture (paintings, music, literature, portraits of political leaders of the country, etc.).

Thus, the study of image dynamics over a long period has shown the presence of positive trends in changing stereotypes about Russia in Japan. The results of the research showed that interest in Russia in Japan was quite high and intercultural communication between the countries in the period 2000-2005. actively developed in a positive direction, which confirms the hypothesis about the importance of political relations as a key factor in building a positive image of the country.

The stereotypes of the Russian people existing in Japanese society are determined by the peculiarities of the formation of Russian-Japanese relations. In addition, the relationship between political events, the general level of political relations between countries and the dynamics of the image was revealed. 
There is no doubt that the emergence of a «new image» of Russia in Japan associated with the civilian population is due to a decrease in the concentration of Russian troops on the Russian-Japanese borders and the desire to resolve the territorial conflict.

\section{Works Cited}

Anne M. Cooper-Chen. Cartoon Cultures: The Globalization of Japanese Popular Media. Peter Lang Publishing, Inc., New York, 2010. Pp. 122-136.

Barker C., Jane E. A. Cultural Studies: Theory and Practice. London: SAGE. 2008. [Электронный pecypc] URL: https://goo.gl/y4pVea (Accessed 10 April 2018).

Brenner Robin E. Understanding Manga and Anime. Greenwood Publishing Group, 2007. P. 13.

Burke P. What is Cultural History? Polity Press. 2008. Pp. 30-31.

Japan GDP - Gross Domestic Product. [Электронный ресурс]

URL: https://countryeconomy.com/gdp/japan?year=2005 (Accessed 16 June 2018).

Japan's Quest for Empire 1931-1945. Dr Susan Townsend. 2011-03-30. [Электронный pecypc]

URL: http://www.bbc.co.uk/history/worldwars/wwtwo/japan_quest_empire_01.shtml (Accessed 16 June 2018).

Kimura H. The Kurillian Knot: A History of Japanese-Russian Border Negotiations. Stanford University Press, 2008. Pp. 167-168.

Manga Anthology Circulations 2004-2006. [Электронный ресурс] URL: http://www.comipress.com/article/2007/12/26/3040 (Accessed 17 June 2018).

Manovich L., Douglass J., Huber W. Understanding scanlation: how to read one million fantranslated manga pages. Online Magazine of the Visual Narrative ISSN 1780-678X. 2010.

Rees L. Horror in the East: Japan and the Atrocities of World War II. Perseus Books Group, 2001. Pp. 15-16.

Scanning the Media.Japanese Anime - Within Sight of a 10 Trillion Yen Global Markets. [Электронный ресурс]

URL:https://web.archive.org/web/20050310035337/www.jmrlsi.co.jp/english/inthemedia/ scan/2005/01.html (Accessed 17 June 2018).

Slavinsky B. The Japanese-Soviet Neutrality Pact: A Diplomatic History, 1941-1945. Boris Slavinsky, trans. Geoffrey Jukes. Nissan Institute/RoutledgeCurzon Japanese Studies Series. London and New York: RoutledgeCurzon, 2004. Pp. 188. 
Soviet denunciation of pact with Japan (The Department of State Bulletin, Vol. XII, No. 305, April 29, 1945). [Электронный ресурс] URL: http://www.jewishvirtuallibrary.org/ussrdeclaration-of-war-on-japan-august-1945 (Accessed 4 June 2018).

Thomas P.L. Ignoring Poverty in the U.S.: The Corporate Takeover of Public Education. Charlotte. IAP, 2012.

Алепко Н.А. Российско-японские экономические отношения на Дальнем Востоке России: автореф. дис. ... канд. ист. наук. Хабаровск, 2009.

Ассман, А. Длинная тень прошлого: Мемориальная культура и историческая политика / Алейда Ассман; пер. с нем. Бориса Хлебникова. М.: Новое литературное обозрение, 2014.

Бергер П., Лукман Т.: Социальное конструирование реальности. [Электронный ресурс]: http://socioline.ru/pages/p-berger-t-lukman-sotsialnoe-konstruirovanie-realnosti (Accessed 13 April 2018).).

Володин А.Ю. Digital Humanities (цифровые гуманитарные науки): в поисках самоопределения // Вестн. Перм. ун-та. Сер. История. 2014. №3 (26). Рр. 5-12.

Воробьёва Т.А. Советско-японский пакт о нейтралитете 1941 г. В современной отечественной историографии // Вестник ВятГУ. 2010. №2-1.

Высоков М.С., Василевский А.А., Костанов А.И., Ищенко М.И. История Сахалина и Курильских островов с древнейших времен до начала XXI столетия / отв. Ред. М. С. Высоков. Южно-Сахалинск: Сахалинское книжное Издательство, 2008.

Дарнтон Р. Великое кошачье побоище и другие эпизоды из истории французской культуры. М.: «Новое литературное обозрение», 2002.

Деркач Ф. Манга. Отличительные особенности // Вестник Иркутского госуниверситета. 2003. № 3.

Договор нейтралитета между Союзом Советских Социалистических Республик и Японией, от 13 апреля 1941 года. [Электронный ресурс]

URL: http://hrono.ru/dokum/194_dok/19410413jap.php (Accessed 7 May 2018).

Ёмота И. Теория каваи / Инухико Ёмота; пер. с японского, вступ. статья А. Беляева. М.: Новое литературное обозрение, 2018. Рр. 24-32.

История Сахалина и Курильских островов с древнейших времен до начала XXI столетия / М. С. Высоков, А. А. Василевский, А. И. Костанов, М. И. Ищенко; отв. Ред. М. С. Высоков. Южно-Сахалинск: Сахалинское книжное Издательство, 2008. 712 с. [Электронный ресурc] URL: http://www.kuriles-history.ru/book/chapter/23/ (Accessed 12 July 2018).

Могила светлячков [Hotaru no haka] [Электронный ресурc] URL: https://goo.gl/9hvwrA (Accessed 16 June 2018).

Николаева Н.С. Япония - Европа. Диалог в искусстве. Середина XVI - начало XX века. М., 1996. Рp. 225-227.

Попова А.А. Формирование образа Японии в российском общественном сознании, XVII первая четверть XX вв.: автореф. дис. ... канд. ист. наук. Краснодар, 2011. 
Русакова О.Ф. Концепт «Мягкой» силы (soft power) в современной политической философии // Научный ежегодник ИФиП УрО РАН. 2010. № 10.

Сидякина Н.И. Визуальная самопрезентация России и Японии в период русскояпонской войны 1904-1905 гг. // Гуманитарные исследования в Восточной Сибири и на Дальнем Востоке. № 2 (28). 2014;

Славинский Б.Н. Советская оккупация Курильских островов (август - сентябрь 1945 г.). Документальное исследование. М.: ТОО «Лотос», 1993. Рр. 14-15.

Стрельцов Д. Вопросы исторического прошлого в российско-японских отношениях [Электронный ресурс]. URL: https://carnegie.ru/2016/05/23/ru-pub-63644 (Accessed 16 July 2018).

Суэцугу И. Вехи на пути к заключению мирного договора между Японией и Россией: 88 вопросов от граждан России: Пер. с яп. М.: Материк, 2000.

Февр Л. Бои за историю. М.: «Наука». 1991. Рр. 67-71; Кром М.М. Историческая антропология: Пособие к лекционному курсу [Электронный ресурc] URL: http://www.countries.ru/library/antropology/krom/index.htm (Accessed 10 April 2018).

Ященко Ю.А., Фадеева А.С., Ященко А.В. Образы России в визуальной медиакультуре Японии на рубеже XX - XXI вв.: маркеры пространства «русскости»// Естественнонаучные методы в цифровой гуманитарной среде: материалы Bсерос. науч. конф. с междунар. участием (г. Пермь, 15-18 мая 2018 г.). Перм. гос. нац. исслед. ун-т. Пермь, 2018. Рр. 252-255

Ященко Ю.В. Динамика образа России в медиакультуре Японии в 1993-2005 гг.: влияние русско-японских отношений // Вестник молодых ученых ПГНИУ [Электронный ресурс]: сб. науч. тр. / отв. редактор Р.Р. Гильмутдинов; Перм. гос. нац. исслед. ун-т. Электрон. дан. Пермь, 2015. Вып. 6. ISBN ISBN 978-5-79442862. 
